\title{
A new record of a great white shark, Carcharodon carcharias (Chondrichthyes: Lamnidae) in the Strait of Sicily, Central Mediterranean Sea
}

\author{
Danilo SCANNELLA ${ }^{1}$, Michele Luca GERACI ${ }^{1,2^{*}}$, Fabio FALSONE ${ }^{1}$, Francesco \\ COLLOCA $^{3}$, Bruno ZAVA ${ }^{4,5}$, Fabrizio SERENA ${ }^{1}$, \\ Federico Di MAIO ${ }^{1,2}$ and Sergio VITALE ${ }^{1}$ \\ ${ }^{1}$ Institute for Marine Biological Resources and Biotechnology (IRBIM), National Research \\ Council - CNR, Mazara del Vallo (TP), Italy \\ ${ }^{2}$ Department of Biological, Geological and Environmental Sciences (BiGeA) - Marine biology \\ and fisheries laboratory of Fano (PU), University of Bologna (BO), Italy \\ ${ }^{3}$ Stazione Zoologica Anton Dohrn, Integrative Marine Ecology Department, Villa Comunale, \\ 80121 Naples, Italy \\ ${ }^{4}$ Wilderness studi ambientali, Via Cruillas, 27, 90146 Palermo, Italy \\ ${ }^{5}$ Museo Civico di Storia Naturale, via degli Studi 9, 97013 Comiso (Ragusa), Italy
}

*Corresponding author, e-mail: micheleluca.geraci2@unibo.it

In November 2015 an immature male individual of great white shark, Carcharodon carcharias (Linnaeus 1758), was caught as by-catch by a bottom trawler in the Strait of Sicily, in the Central Mediterranean Sea. The shark, reaching $266 \mathrm{~cm}$ in length and weighing $290 \mathrm{Kg}$, was identified and measured by means of a video provided by fishers. This record is discussed considering the available information on the presence of the great white shark in the area and confirms the importance of the Strait of Sicily for the conservation of this vulnerable species.

Key words: Mediterranean Sea, elasmobranchs, large pelagic shark, biodiversity, threatened species 


\section{INTRODUCTION}

Conservation of large pelagic sharks is challenging (VINCENT, A.C.J. \& H.J HALL 1996; ROBERTS, C.M. \& J.P. HAWKINS 1999) because they are vulnerable to extinction and recover slowly from stock exploitation (BARKER, M. J. \& V. SCHLUESSEL 2005; GARCÌA et al., 2008). It is well known that pelagic sharks are in a high position in the trophic food web, slow growth, delayed sexual maturity, low fecundity/fertility, and long-life spans (DULVY et al., 2014). Globally, apex predators, such as the great white shark Carcharodon carcharias (Linnaeus, 1758), play important controlling roles to the structure and functioning of marine ecosystems through direct and indirect predatory effects (STEVENS et al., 2000; BASCOMPTE et al., 2005; HEITHAUS et al., 2008). Several studies have indicated that trophic cascades might be occurring in marine ecosystems because of the decreasing apex predator abundance and the consequent predator release effect on their prey (MYERS et al., 2007; BAUM, J. K. \& B. WORM 2009; GRUBBS et al., 2016).

The great white shark is probably the most charismatic species of shark and, although intensively studied around the world many aspects of its natural history, biology and ecology remain poorly understood (HUVENEERS et al., 2018). The distribution of the species in the oceans appears to be discontinuous and major aggregations tend to occur close to highly productive habitats where marine mammals, particularly pinnipeds, and big fish (e.g. blue fin tuna) are abundant (COMPAGNO, 1984; FERGUSSON, 2002).

MORO et al. (2020) reported 773 records of great white shark in Mediterranean Sea from the end of the Middle Ages (1453) to 2016, mainly distributed in the central-western Mediterranean Sea. In the Strait of Sicily (central Mediterranean), this species was documented either along the coast of Sicily (56 times from 1666 to 2016: KARACHLE et al., 2016) or in Tunisian and Maltese waters (FERGUSSON, 1996; STORAI et al., 2000; FERGUSSON, 2002; SAIDI et al., 2005).

Genetic studies (GUBILI et al., 2010; ANDREOTTI et al., 2016; LEONE et al., 2020), suggested that the Mediterranean population of $C$. carcharias has probably the lowest genetic diversity at global
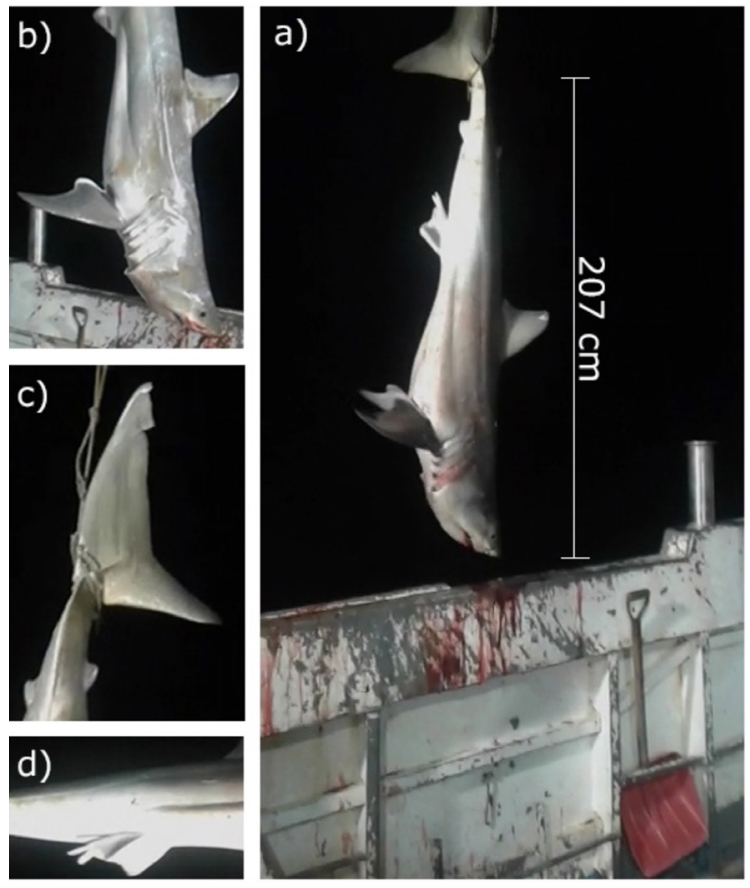

Fig. 1. Carcharodon carcharias immature male caught during trawl fishery operation, a) whole individual, b) details of pectoral fins, c) caudal fin, d) claspers

level also due to a lack of connectivity with the closer ocean populations. Low levels of genetic diversity would prevent this species from recovering quickly to a healthier population status and thus increasing its extinction risks.

The great white shark is widely recognized as a highly threatened species, haunted and worthy of protection. Indeed, it is listed at global level as "vulnerable" by the International Union for Conservation of Nature (IUCN) (FERGUSSON et al., 2009) and is included in Appendix II of the Convention on International Trade in Endangered Species (CITES).

At Mediterranean level, this species is classified as "critically endangered" by IUCN (DULVY et al., 2016; SOLDO et al., 2016) and it is also included in the Barcelona Convention Annex II SPA/BD Protocol. Furthermore, the General Fisheries Commission for the Mediterranean Sea (GFCM) states that white sharks caught during fishing operation must be promptly released unharmed and alive to the greatest extent possible. Otherwise, specimens of sharks shall not be retained on board, landed or sold (Recommendation GFCM/42/2018/2). 


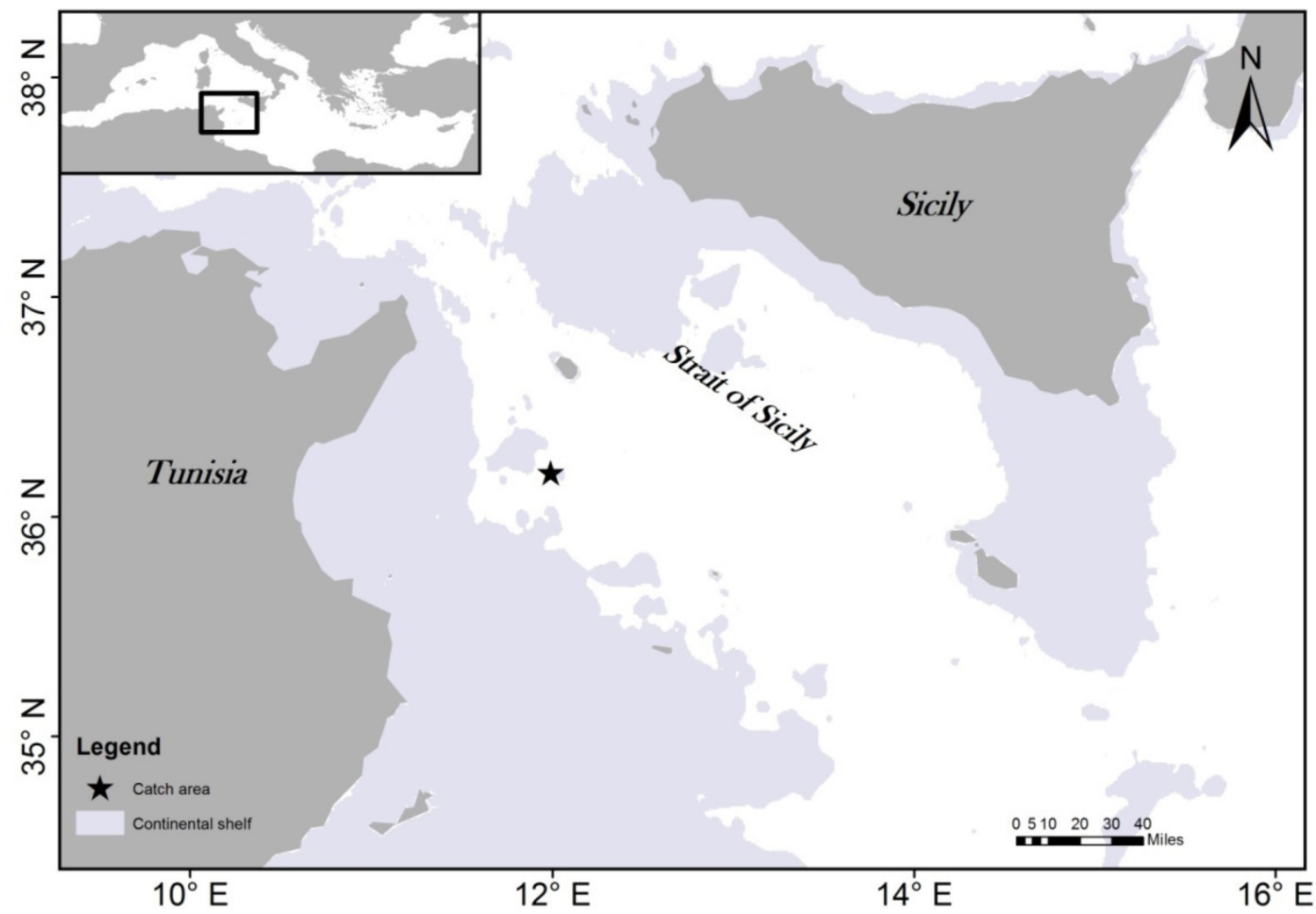

Fig. 2. Map showing the approximate location of the great white shark capture reported in the present contribution

Consequently, it is worth highlighting the importance of each single record of C. carcharias with the overall goal to update its presence and improve our understanding on the spatial pattern of its life cycle.

\section{MATERIAL AND METHODS}

In November 2015 an individual of great white shark was accidentally caught by a commercial bottom trawler at about $300 \mathrm{~m}$ depth, 27 miles off the south coast of Pantelleria Island (approximate coordinates $36^{\circ} 18^{\prime} \mathrm{N}, 11^{\circ} 55^{\prime}$ E) (Fig.1 \& Fig.2). The shark was identified according to descriptions given by COMPAGNO (1984). The biometric data were obtained by frames of a video taken by a fisher with his smartphone by means of ImageJ software (SCHNEIDER et al., 2012) using as standard the size of the shovel (Fig.1a). Then, measurements were compared as percentage of total length (TL) with information reported by KABAKASAL, H.
\& S. Ö. GEDIKOGLU (2008) (Table 1). Afterwards, the weight was estimated from the total lengthweight relationship reported by MANCUSI et al. (2020). The maturity stage was attributed using the relationship between clasper length and total length provided by KLIMLEY, A.P. \& D.G. AINLEY (1998).

It's worth pointing out that the shark was released still alive by the fishers even if the poor state of health of the shark was clear due to some blood loss in addition to the long handling time on the vessel deck.

\section{RESULTS AND DISCUSSION}

The individual was estimated to be $266 \mathrm{~cm}$ TL, $207 \mathrm{~cm}$ PCL (pre-caudal length) and about $290 \mathrm{~kg}$ of total weight. As shown in table 1, biometry expressed as percentage of TL resulted quite similar to the measurements reported for a male individual caught in Turkey (KABAKASAL, H. \& S. Ö. GEDIKOGLU 2008). Slight differences 
were recorded for head length, pre-first dorsal length, pre-second dorsal length, pre-pelvic length, interdorsal space, pectoral-pelvic space and pelvic-anal space (Table 1).

The dimension of the claspers indicated that the young white male shark was still immature as expected considering that previous studies indicated that males attain their first maturity at 350 - 400 cm TL (PRATT, 1996; COMPAGNO, 2001; SERENA et al., 2014). However, a wide geographic variation in length at first sexual maturity was reported by CLIFF et al. (1989).

In the Mediterranean Sea, maturity data on the species are scattered, mainly limited to incidental captures or sightings. Only a few studies concern these bio-ecological aspects (e.g. SERENA et al., 2014; BOLDROCCHI et al., 2017). The great white shark is a "K-selected" species with slow growth rate and high longevity, late maturity, long gestation period, low fecundity and probably small sized populations. These peculiar lifehistory traits indicate that the rebuilding time of great white shark populations in response to fisheries can be very high (BRUCE, 2008). Therefore, the decline of the Mediterranean great white shark population (DULVY et al., 2016; SOLDO et al., 2016), like highlighted for other large predatory sharks (FERRETTI et al., 2008), might be due to both their reproductive strategy and to the strong increase of fishing pressure recorded in the last decades (RUSSO et al., 2014; BOLDROCCHI et al., 2017; MANCUSI et al., 2020; MORO et al., 2020).

The present record of a young great white shark in the Strait of Sicily, although incidentally fished, confirms that trawl fisheries can impact juvenile and neonatal specimens as reported by VACCHI, M. \& F. SERENA (1997). Fisheries that catch both juvenile and adult specimens have been documented in Tunisian waters whilst using different gear such as longliners (FERGUSSON, 2002), trawlers and purse seiners (BRADAII, M. N. AND B. SAÏDI 2013) indicating the importance of the area for the Mediterranean great white shark population. The Strait of Sicily is indeed considered the "core area" of the population also playing a key role as a parturition and nursery area (FERGUSSON, 1996, SAIDI et al., 2005; BRADAÏ, M. N. AND B. SAÏDI 2013; RAFRAFINOUIRA et al., 2015).
Given the high risks of extinction of the great white shark in the Mediterranean Sea, it would be advisable to enforce measures to minimize the mortality due to commercial fishing. With this aim in mind any improvement on the ongoing knowledge on the species-fisheries interactions (e.g main gears, periods, areas, sizes, etc.) would be important to enforce ad-hoc conservation measures for pelagic as well as demersal sharks (RAGONESE et al., 2013; GERACI et al., 2017; COLLOCA et. al., 2019). Raising fishermen awareness on the ecological importance of the species for the Mediterranean marine ecosystem is also extremely important in terms of species conservation. In this regard it would be advisable to also disseminate protocols for properly handling and releasing safely the captured individuals.

\section{ACKNOWLEDGMENTS}

The authors wish to thank the anonymous fisher as well as our colleague Giusto Giovan Battista for the video provided. We are also grateful to Dr Fabio Fiorentino for the many constructive comments and help, which greatly improved the manuscript. In addition, we thank Dr Martina Castelli for the English editing.

\section{REFERENCES}

ANDREOTTI, S., S. VON DER HEYDEN, R. HENRIQUES, M. RUTZEN, M. MEŸER, M.H. OOSTHUIZEN, \& C.A. MATTHEE. 2016. New insights into the evolutionary history of white sharks, Carcharodon carcharias. J Biogeogr, 43: 328-339

BARKER, M.J. \& V. SCHLUESSEL. 2005. Managing global shark fisheries: Suggestions for prioritizing management strategies. Aquat Conserv. 15:325-347.

BASCOMPTE, J., C.J. MELIÀN \& E. SALA. 2005. Interaction strength combinations and the overfishing of a marine food web. P. Natl. Acad. Sci. USA, 102:5443-5447.

BAUM, J.K. \& B. WORM. 2009. Cascading topdown effects of changing oceanic predator abundances. J. Anim. Ecol. 78:699-714. 
BOLDROCCHI, G., J. KISZKA, S. PURKIS, T. STORAI, L. ZINZULA \& D. BURKHOLDER. 2017. Distribution, ecology, and status of the white shark, Carcharodon carcharias, in the Mediterranean Sea. Rev Fish Biol Fisher 27: 515-534.

BRADAÏ, M.N., \& B. SAÏDI. 2013. On the occurrence of the great white shark (Carcharodon carcharias) in Tunisian coasts, Rap. Comm. Int. Mer Médit., 2013, vol. 40, p. 489.

BRUCE, B.D. 2008. The biology and ecology of the white shark, Carcharodon carcharias. Sharks of the open ocean: biology, fisheries and conservation. Oxford, UK, Blackwell Publishing, 69-81.

CLIFF, G., S.F.J. DUDLEY \& B. DAVIS. 1989. Sharks caught in the protective gill nets off Natal, South Africa. 2. The great white shark Carcharodon carcharias (Linnaeus). S Afr J Marine Sci 8:131-144.

COLLOCA, F., D. SCANNELLA, M.L. GERACI, F. FALSONE, G. BATISTA, S. VITALE, M. DI LORENZO \& G. BONO. 2019. British sharks in Sicily: records of long distance migration of tope shark (Galeorhinus galeus) from Northeastern Atlantic to Mediterranean Sea. Mediterranean Marine Science, 20:309-313.

COMPAGNO, L.J.V. 1984. Sharks of the world. An annotated and illustrated catalogue of shark species known to date. FAO Fish. Synop, 125 (4).

COMPAGNO, L.J.V. 2001. Sharks of the World. An annotated and illustrated catalogue of the shark species known to date, vol 2. Bullhead, mackerel and carpet sharks (Heterodontiformes, Lamniformes and Orectolobiformes). FAO species catalogue for fishery purposes, 1: viii+1-269.

DULVY, N.K., S.L. FOWLER, J.A. MUSICK, R.D. CAVANAGH, P.M. KYNE, L.R. HARRISON, J.K. CARLSON, L.N.K. DAVIDSON, S.V. FORDHAM, M.P. FRANCIS, C.M. POLLOCK, C.A. SIMPFENDORFER, G.H. BURGESS, K.E. CARPENTER, L.J.V. COMPAGNO, D.A. EBERT, C. GIBSON, M.R. HEUPEL, S.R. LIVINGSTONE, J.C. SANCIANGCO, J.D. STEVENS, S. VALENTI \& W.T. WHITE. 2014. Extinction risk and conservation of the world's sharks and rays. Elife, 3, e00590

FERGUSSON, I.K. 1996. Report on the distribution and autoecology of the white shark Carcharodon carcharias in the North-Eastern Atlantic and Mediterranean Sea. In: A.P. Klimley and D.G. Ainley (Editors), Great white sharks: Ecology and Behaviour. Academic Press, Orlando, USA, pp. 321-345.

FERGUSSON, I.K, L.J.V. COMPAGNO \& M. MARKS. 2009. Carcharodon carcharias. The IUCN Red List of Threatened Species: e.T3855A10133872.

FERGUSSON, I.K. 2002. Occurrence and biology of the great white shark Carcharodon carcharias in the Central Mediterranean Sea: A review. In: M. Vacchi, G. La Mesa, F. Serena and B. Seret (Editors), Proceedings of the 4th European Elasmobranch Association Meeting, Livorno (Italy), pp. 7-30.

FERRETTI, F., B. WORM, G.L. BRITTEN, M.R. HEITHAUS \& H.K. LOTZE. 2010. Patterns and ecosystem consequences of shark declines in the ocean. Ecol Lett, 13:1055-1071.

GARCÍA, V.B., L.O. LUCIFORA \& R.A. MYERS. 2008. The importance of habitat and life history to extinction risk in sharks, skates, rays and chimeras. Proc. Biol. Sci. 275: 83-89

GERACI, M.L., S. RAGONESE, G. NORRITO, D. SCANNELLA, F. FALSONE \& V. SERGIO. 2017. A tale on the demersal Chondrichthyes off the Southern Coast of the Sicily through 20 years of scientific survey. (2017). In: Chondrichthyes. Luis Fernando Rodrigues-Filho (Editor). ISBN 978-953-51-5403-7.

GRUBBS, R.D., J.K. CARLSON, J.G. ROMINE, T.H. CURTIS, W.D. MCELROY, C.T. MCCANDLESS \& J.A. MUSICK. 2016. Critical assessment and ramifications of a purported marine trophic cascade. Sci Rep-UK, 6, 20970.

GUBILI, R.B., E. KALKAN, S.Ü. KARHAN, C.S. JONES, D.W. SIMS, H. KABASAKAL, A.P. MARTIN \& L.R. NOBLE. 2010. Antipodean white sharks on a Mediterranean walkabout? Historical dispersal leads to genetic discontinuity and an endangered anomalous population. P Roy Soc B-Biol Sci, 278:1679-1686.

HEITHAUS, M.R., A.J. WIRSING, J.A. THOMSON \& D.A. BURKHOLDER. 2008. A review of lethal and non-lethal effects of predators on adult marine turtles. J Exp Mar Biol Ecol, 356:4351. 
HUVENEERS, C., K. APPS, E.E. BECERRIL-GARCÍA, B. BRUCE, P.A. BUTCHER, A.B. CARLISLE, T.K. CHAPPLE, H.M. CHRISTIANSEN, G. CLIFF, T.H. CURTIS, T.S. DALY-ENGEL, H. DEWAR, M.L. DICKEN, M.L. DOMEIER, C.A.J. DUFFY, R.FORD, M.P. FRANCIS, G.C.A. FRENCH, F. GALVÁNMAGAÑA，E. GARCÍA-RODRÍGUEZ，E. GENNARI, B. GRAHAM, B. HAYDEN, E.M. HOYOSPADILLA, N.E. HUSSEY, O.J.D. JEWELL, S.J. JORGENSEN, A.A. KOCK, C.G. LOWE, K. LYONS, L. MEYER, G. OELOFSE, E.C. OÑATE-GONZÁLEZ, H. OOSTHUIZEN, J.B. O'SULLIVAN, K. RAMM, G. SKOMAL, S. SLOAN, M.J. SMALE, O. SOSANISHIZAKI, E. SPERONE, E. TAMBURIN, A. V. TOWNER, M.A. WCISEL, K.C. WENG \& J.M. WERRY. 2018. Future research directions on the "Elusive" White Shark. FRONT MAR SCI, 5: 455 .

KARACHLE, P., A. ANGELIDIS, G. APOSTOLOPOULOS, D. AYAS, M. BALLESTEROS, C. BONNICI, M. BRODERSEN, L. CASTRIOTA, N. CHALARI, J. COTTALORDA, F. CROCETTA, A. DEIDUN, Ž. DODO, A. DOGRAMMATZI, J. DULČIĆ, F. FIORENTINO, O. GÖNÜLAL, J. HARMELIN, G. INSACCO, D. IZQUIERDO-GÓMEZ, A. IZQUIERDO-MUÑOZ, A. JOKSIMOVIĆ, S. KAVADAS, M. MALAQUIAS, E. MADRENAS, D. MASSI, P. MICARELLI, D. MINCHIN, U. ÖNAL, P. OVALIS, D. POURSANIDIS, A. SIAPATIS, E. SPERONE, A. SPINELLI, C. STAMOULI, F. TIRALONGO, S. TUNÇER, D. YAGLIOGLU, B. ZAVA \& A. ZENETOS. 2016. New Mediterranean Biodiversity Records (March 2016). Mediterr Mar Sci, 17:230-252.

KABASAKAL, H. \& S.Ö. GEDIKOĞLU. 2008. Two new-born great white sharks, Carcharodon carcharias (Linnaeus, 1758) (Lamniformes; Lamnidae) from Turkish waters of the north Aegean Sea. Acta Adriat., 49:125-135.

KLIMLEY, A.P. \& D.G. AINLEY. 1998. Great white sharks: the biology of Carcharodon carcharias. Academic Press.

LEONE, A., G.N. PUNCHER, F. FERRETTI, E. SPERONE, S. TRIPEPI, P. MICARELLI, A. GAMBARELLI, M. SARÀ, M. ARCULEO, G. DORIA, F. GARIBALDI, N. BRESSI, A. DALL'ASTA, D. MINELLI, E. CILLI, S. VANNI, F. SERENA, P. DÍAZ-JAIMES, G. BAELE, A. CARIANI \& F. TINTI.
2020. Pliocene colonization of the Mediterranean by Great White Shark inferred from fossil records, historical jaws, phylogeographic and divergence time analyses. Journal of Biogeography, 47(5), 1119-1129.

MANCUSI, C., R. BAINO, C. FORTUNA, L. DE SOLA, G. MOREY, M. BRADAI, A. KALLIANOTIS, A. SOLDO, F. HEMIDA, A. SAAD, M. DIMECH, P. PERISTERAKI, M. BARICHE, S. CLÒ, E. DE SABATA, L. CASTELLANO, F. GARIBALDI, L. LANTERI, F. TINTI, A. PAIS, E. SPERONE, P. MICARELLI, F. POISSON, L. SION, R. CARLUCCI, D. CEBRIAN-MENCHERO, B. SÉRET, F. FERRETTI, A. EL-FAR, I. SAYGU, E. SHAKMAN, A. BARTOLI, J. GUALLART, D. DAMALAS, P. MEGALOFONOU, M. VACCHI, M. BOTTARO, G. NOTARBARTOLO DI SCIARA, M. FOLLESA, R. CANNAS, H. KABASAKAL, B. ZAVA, G. CAVLAN, A. JUNG, M. ABUDAYA, J. KOLITARI, A. BARASH, A. JOKSIMOVIC, B. MARČETA, L. GONZALEZ VILAS, F. TIRALONGO, I. GIOVOS, F. BARGNESI, S. LELLI, M. BARONE, S. MORO, C. MAZZOLDI, C. CHARIS, A. ABELLA, \& F. SERENA. 2020. MEDLEM database, a data collection on large Elasmobranchs in the Mediterranean and Black seas. Mediterr. Mar. Sci., 21: 276-288.

MORO S., G. JONA-LASINIO, B. BLOCK, F. MICHELI, G. DE LEO, F. SERENA, M. BOTTARO, U. SCACCO \& F. FERRETTI. 2020. Abundance and distribution of the white shark in the Mediterranean Sea. Fish Fish, 21: 338-349.

MYERS, R.A., J.K. BAUM, T.D. SHEPHERD, S.P. POWERS \& C.H. PETERSON. 2007. Cascading effects of the loss of apex predatory sharks from a coastal ocean. Science 315:1846-1850.

PRATT, H.L.JR. 1996. Reproduction in the male white shark (Carcharodon carcharias). In: A. P. Klimley and D.G. Ainley (Editors), Great white sharks: Ecology and Behaviour, Academic Press, Orlando, USA Roberts CM, and Hawkins JP. Extinction risk in the sea. Trends in Ecology \& Evolution, 1999 14(6). RAFRAFI-NOUIRA, S., O. EL KAMEL-MOUTALIBI, C. REYNAUD, M. BOUMAÏZA \& C. CAPAPÉ. 2015. Additional and unusual captures of elasmobranch species from the northern coast of Tunisia (central Mediterranean). J Ichthyol, 55:836-848. 
RAGONESE, S., S. VITALE, M. DIMECH \& S. MAZZOLA. 2013. Abundances of demersal sharks and chimaera from 1994-2009 scientific surveys in the central Mediterranean Sea. PloS one, 8(9), e74865.

ROBERTS, C.M. \& J.P. HAWKINS. 1999. Extinction risk in the sea. Trends in Ecology \& Evolution 14:241-246.

RUSSO, T., A. PARISI, G. GAROFALO, M. GRISTINA, S. CATAUDELLA \& F. FIORENTINO. 2014. SMART: a spatially explicit bio-economic model for assessing and managing demersal fisheries, with an application to Italian trawlers in the Strait of Sicily. PloS one, 9(1), e86222.

SAIDI, B., M.N. BRADAI, A. BOUAÏN, O. GUÉLORGET \& C. CAPAPÉ. 2005. Capture of a pregnant female white shark, Carcharodon carcharias (Lamnidae) in the Gulf of Gabès (southern Tunisia, central Mediterranean) with comments on oophagy in sharks. Cybium, 29:303-307.

SCHNEIDER, C.A., W.S. RASBAND \& K.W. ELICEIRI. 2012. NIH Image to ImageJ: 25 years of image analysis. Nature methods 9: 671-675
SERENA, F., C. MANCUSI \& M. BARONE. 2014. MEDiterranean Large Elasmobranchs Monitoring. Protocollo di acquisizione dati. SharkLife program, Roma. $130 \mathrm{pp}$.

SOLDO, A., M.N BRADAI \& R.H.L. WALLS. 2016. Carcharodon carcharias. The IUCN Red List of Threatened Species 2016: e.T3855A16527829. Downloaded on 17 April 2019.

STEVENS, J.D., R. BONFIL, N.K. DULVY \& P.A. WALKER. 2000. The effects of fishing on sharks, rays, and chimaeras (chondrichthyans), and the implications for marine ecosystems. ICES J Mar Sci, 57:476-494.

STORAI, T., A. MOJETTA, M. ZUFFA \& S. GIULIANI. 2000. Nuove segnalazioni di Carcharodon carcharias (L.) nel Mediterraneo centrale. Atti Soc Tosc Sci Nat Mem (B), 107:139142.

VACCHI, M. \& F. SERENA. 1997. Squali di notevoli dimensioni nel Mediterraneo centrale. Quad Civica Stazione Idrobiol Milano, 22:39-45.

VINCENT, A.C.J. \& H.J. HALL. 1996. The threatened status of marine fishes. Trends Ecol Evol $11: 360-361$.

Received: 23 July 2019

Accepted: 7 September 2020 


\title{
Novi nalaz velike bijele psine, Carcharodon carcharias (Chondrichthyes: Lamnidae) u Sicilijskom tjesnacu, Sredozemno more
}

\author{
Danilo SCANNELLA, Michele Luca GERACI, Fabio FALSONE, \\ Francesco COLLOCA, Bruno ZAVA, Fabrizio SERENA, \\ Federico Di MAIO i Sergio VITALE
}

*Kontakt, e-pošta: micheleluca.geraci2@unibo.it

\begin{abstract}
SAŽETAK
U studenom 2015. ulovljen je nezreli mužjak velike bijele psine, Carcharodon carcharias (Linnaeus 1758), koćom u Sicilijskom tjesnacu (srednje Sredozemno more).

Morski pas, koji je dosegao $266 \mathrm{~cm}$ duljine i težinu od $290 \mathrm{~kg}$, identificiran je i izmjeren pomoću videozapisa koji su osigurali ribari.

U ovom se radu raspravlja, s obzirom na dostupne informacije o prisutnosti velike bijele psine a na tom području i potvrđuje važnost Sicilijskog tjesnaca za očuvanje ove ranjive vrste.
\end{abstract}

Ključne riječi: Sredozemno more, hrskavičnjače, Carcharodon carcharias, biološka raznolikost, ugrožene vrste 